\title{
The Role of Coping in Salespeople's Satisfaction and Its Effect on Salespeople's Ethics
}

\author{
Rajesh V. Srivastava
}

$\mathrm{PhD}$, Associate Professor of Marketing, Department of Marketing, Middle Tennessee State University, USA

\begin{abstract}
Stress affects the health of salespeople on a regular basis. It is a weapon of mass destruction as three out of every four workes all over the world consider their work as stressful. It contributes to over 100,000 deaths every year. Thus, it is resulting in becoming a very important topic to study. As salespeople deal with different roles in their daily job and experience role ambiguity, role conflict and role overload, they are subjected to stress more than other employees of any company do. In this paper, I test the hypothesis that different ways of coping have a different influence on job satisfaction and life satisfaction of salespeople. This paper develops a theoretical model that focuses on the extent to which coping may enhance sales people's job satisfaction and life satisfaction. Based on data collected from 471 salespeople in the US, I conclude that those salespeople that use the right form of coping will end up enhancing job satisfaction and life satisfaction. My model reveals that the efficient form of coping has a major influence in enhancing job satisfaction. A great way to deal with these negative outcomes of sales job is to cope with the stress on a regular basis. Salespeople who take a positive approach or also called a problem-focused approach tend to deal with the stress in much better form; they attack the root cause of it and tend to increase job satisfaction and life satisfaction. While those who take a negative approach or an emotion-focused approach, tend to show a negative effect of stress and display a lower incidence of job satisfaction and life satisfaction. Employees of the companies and especially managers need to be educated on these topics so that when problems arise, they will be prepared to handle them in a manner that will maximize the organization's productivity and reduce stress. The employees should be taught to cope with stress in a positive manner and should be taught to take a problem-focused approach to coping.
\end{abstract}

Keywords: salespeople, stress, problem-focused coping, emotion-focused coping, job satisfaction, life satisfaction, ethics.

JEL Classification: M31, J28, A13.

Cite as: Srivastava, R.V. (2019). The Role of Coping in Salespeople's Satisfaction and Its Effect on Salespeople's Ethics. Business Ethics and Leadership, 3(1), 118-123. http://doi.org/10.21272/bel.3(1).118123.2019.

(C) The Author, 2019. This article is published with open access at Sumy State University.

\section{Introduction}

Stress is the primary cause of more than 100,000 deaths every year (Blanding, 2015). Stress is the contributing factor responsible for almost 10-15\% of all the diseases. Sale is one of the most stress full job and it affects millions of people in the United States. Salespeople are mostly high driven, type A personality individual, and are at risk to a high-level stress. The cost of loss of manpower due to stress is said to cost companies, all over the world, is $\$ 300$ billion a year (Smith, 2012). This is especially important for workers that have to deal with different worldwide cultures. Stress drastically affects the health of the salespeople and affects the individual productivity at work (Ichniowski, Shaw, \& Rennushi, 1997; Tang \& Hammontree, 1992; Chabra, 2016). Almost 75\% of the employees describe their work environment as stressful (Stewart et al., 2003; Niessen et al., 2018). However, research also shows that employees effectively cope with this daily stress and the coping strategies they employ will determine if they can reduce this stress effectively (Srivastava \& Sager, 1999).

Job satisfaction is defined as, "all characteristics of the job itself and the work environment which industrial salesmen find rewarding, fulfilling and satisfying; or frustrating and unsatisfying" (Churchill et al., 1974). Job satisfaction is an important variable in the intention to leave (Mulki et al., 2006) and organizational commitment (Brashear et al., 2003). Job satisfaction is researched as both an antecedent and outcome variable which has important implications. Life satisfaction is a variable that is beginning to gather attention in the employee research field. More and more people are talking about work satisfaction and its effect on the reduction of stress. Life satisfaction also plays an important role in reducing stress. 


\section{Coping}

From almost forty last years coping has been the topic of interest by researchers and especially and its relationship to satisfaction. Stress, a factor in satisfaction, is more effectively alleviated when a combination of suppression and direct coping is used. Aldwin and Revenson (1987) found if people use emotional-focused coping, it will result in more problems in the future due to an increase in emotional distress. An example of a problem is the lack of life satisfaction.

Coping is a popular topic of study on various professional fields and especially with those individuals that are on boundary spanning role. But, first of all, let me discuss what coping is and various types of coping that exists. Cooper et al. (2001) stress that coping can be viewed as either a perceptual construct or a situational construct. When viewed as a perceptual construct, coping occurs as a style of behavior or cognition. A coping style is the approach an individual takes to cope with stress on a job. When it is viewed situational construct, coping occurs as a behavior wherein coping responses vary by situations within individuals and within situations by the individual.

Lazarus and Folkman in their seminal study $(1984,1985)$ identified two styles people use to cope with stress: Problem-Focused Coping (PFC or active coping) and Emotion-Focused Coping (EFC or avoidance coping). PFC is primarily a problem-solving approach. It involves the salesperson's researching a source of stress, generating alternatives, weighing the alternatives in terms of costs and benefits to self and organization, and selecting an alternative based on a balance between cost and benefit (Lazarus and Folkman 1984: 152). Emotion-focused coping is usually defined as aiming to manage the emotional distress that is associated with the situation (Lazarus \& Folkman, 1984) EFC involves a salesperson's governing the emotions that accompany the chronic stress of the sales task. (Lazarus and Folkman 1985). It results in people either ignoring or avoiding the source of stress or doing activities that result in providing them distractions that result in short term relief.

Emotion-focused coping do not benefit workers as they avoid the problem while control-coping strategies do benefit workers by allowing them to deal with a difficult and challenging workload (Koeske et al, 1993). Optimistic salespeople use problem-focused coping while pessimistic salespeople use emotion-focused coping and salespeople who use problem-focused coping are much better in sales presentation than salespeople who use emotion-focused coping (Strutton and Lumpkin, 1993, 1994; Kraft et al., 2019). Research also shows that personal characteristics also influence how salespeople cope with daily stress. Salespeople who are more involved, self-determined, and adaptable to change are more likely to use problem-focused coping. Salespeople who use emotion-focused coping are likely to feel alienated and see change as a threat (Strutton, et al, 1993: 95). Researchers like Srivastava and Sager (1999) studied salespeople using four personal variables: locus of control, task-based self-efficiency, continuance commitment, and social support. Salespeople who use problem-focused coping have a higher internal locus of control and greater self-efficiency beliefs.

\section{Job Satisfaction}

Job satisfaction is one of the most widely studied variable in sales literature. Churchill et al. (1974) define it as, "all characteristics of the job itself and the work environment which the salesman find rewarding, fulfilling and satisfying or frustrating and unsatisfying". Job satisfaction is an affective state of mind when a person's job outcome compares well with the desired outcomes. Job satisfaction has been often studied to understand employee's behavior and attitude. It is also an important factor for various activities like job performance, jobrelated attitude and behavior (Brown and Paterson, 1993, 1994). It is viewed as an attitudinal variable, which assesses how salespeople feel about their job on a daily basis and the variable that has a great effect on daily work. It is one of the most studied variables in sales literature because it related to commitment, performance, turnover intentions, job turnover, role ambiguity, role conflict, role overload and burnout (Brown and Peterson, 1993; Srivastava and Sager, 1999; Srivastava and Tang, 2018; Darmody and Smyth, 2016).

Salespeople experience role stress (role ambiguity and role conflict) on a regular basis, causing enormous job stress. As this stress leads to negative outcomes like a decrease in performance, decrease in organizational commitment, higher intention to leave and lower job satisfaction. Needless to say, these costs a lot of money to the workplace. In order to reduce this stress, salespeople cope with daily stress. Salespeople who act to reduce the cause of stress using problem-focused coping resulting in higher job satisfaction. Salespeople who use emotion-focused coping, only able to avoid the cause of stress, hence will have lower job satisfaction. So the hypothesis is

$\mathrm{H}_{1}$ : Salespeople who use problem-focused coping will have higher job satisfaction while salespeople who use emotion-focused coping will have lower job satisfaction. 


\section{Life Satisfaction}

Life satisfaction is defined as a pleasurable emotional state resulting from the appraisal of one's job (Locke, 1969). It deals with various aspects of ones' quality of life or the overall satisfaction of life (Diener et al., 1985; Tang, 1992, 2007). Happy workers are successful workers. When they are happy, they perform better and contribute to the performance of the company. However, work-related stress may result in employees' illness, absenteeism, and propensity to leave (Johonson et al., 2000; Tang and Hammontree, 1992). Stress has a negative effect on the employees' emotional state and thus reduces job satisfaction and life satisfaction (Arndt and Harkins, 2013; Mayo and Mallin, 2014; Srivastava and Tang, 2018). So, salespeople who cope better are able to reduce the stress hence improving their life satisfaction. Salespeople who use problem-focused coping will have higher life satisfaction while salespeople who use emotion-focused coping will have lower life satisfaction. Thus, the hypothesis,

$\mathrm{H}_{2}$ : Salespeople who use problem-focused coping will have higher life satisfaction while salespeople who use emotion-focused coping will have lower life satisfaction.

\section{Methodology}

\section{Sample}

Salespersons from the manufacturer of specialty chemical products were asked to fill out a questionnaire regarding their daily work. This organization employed 1,200 salespeople and 100 sales managers arrayed into several geographic divisions. Twenty-five percent of salespeople were females, although females represent about 40 percent of new hires.

We mailed Questionnaires to 1,200 salespeople's home address. We obtained responses from 918 salespeople (return rate $=76.5 \%$ ). The actual sample size was 512, due to our specific variables selected for our theoretical model.

\section{Measure}

We used job satisfaction and life satisfaction as our outcome variables -6 items were used in job satisfaction and 6 items were used in life satisfaction. We selected, problem-focused coping and emotion-focused coping, from Ways of Coping Checklist (Folkman and Lazarus, 1980, 1985). A 5-point Likert type frequency response format was used with the following scale anchors: strongly disagree (1) to strongly agree (5). The reliabilities (Cronbach's alpha) are provided in Table 1.

Table 1. Descriptive Statistics and Correlations

\begin{tabular}{|c|l|c|c|c|c|c|c|c|}
\hline & \multicolumn{1}{|c|}{ Variables } & M & SD & Alpha & $\mathbf{1}$ & $\mathbf{2}$ & $\mathbf{3}$ & $\mathbf{4}$ \\
\hline 1 & Problem Focused Coping & 3.69 & 0.54 & 0.78 & - & $.25^{* *}$ & $.38^{* *}$ & $-.34^{* *}$ \\
\hline 2 & Emotion Focused Coping & 1.99 & 0.60 & 0.66 & & - & $-.26^{* *}$ & $-.24^{* *}$ \\
\hline 3 & Life Satisfaction & 2.46 & 0.55 & 0.89 & & & - & $.44^{* *}$ \\
\hline 4 & Job Satisfaction & 3.32 & 0.58 & 0.86 & & & & - \\
\hline
\end{tabular}

** Correlation is significant at .01 level ( 2 tailed)

Source: Own elaboration

\section{Results}

\section{Descriptive:}

Table 1 and Table 2 show the mean, standard deviation, Cronbach's alpha, and correlations of all variables at the sub-construct level. The Cronbach alpha reliability is .75 or more except for emotion focused coping. Regression value of coping strategies and the job satisfaction and life satisfaction variables are provided in Table 2 .

Table 2. Models Predicting Coping Style

\begin{tabular}{|lcccc|}
\hline \multicolumn{1}{|c}{ Outcome Variables } & \multicolumn{2}{c|}{ Problem-Focused Coping } & \multicolumn{2}{c|}{ Emotion-Focused Coping } \\
& Beta & $\mathrm{P} \leq$ & Beta & $\mathrm{P} \leq$ \\
\hline Life Satisfaction & .22 & .00 & -.18 & .00 \\
Job Satisfaction & .28 & .00 & -.17 & .00 \\
\hline & \multicolumn{2}{c}{$\mathrm{F}=51.32$} & $\mathrm{p} \leq .000$ & $\mathrm{~F}=22.78 \mathrm{p} \leq 000$ \\
& \multicolumn{2}{c}{ Adjusted R2 $=0.18$} & Adjusted R2 $=0.085$ \\
\hline
\end{tabular}

Source: Own elaboration 
Measurement model:

The emotion-focused coping was negatively related to job satisfaction (-.18) and life satisfaction (-.17), while problem-focused coping was positively related to job satisfaction (.28) and life satisfaction (.22). All these beta values were significant at $\mathrm{p}<.05$ level. Overall $\mathrm{F}$ value was also significant at $\mathrm{p}<.05$ level. This support hypothesis 1 and 2 (See Figure 2). The p value is significant at .00 level.



Figure 1. Model with Direction of Hypothesis

Source: Own elaboration

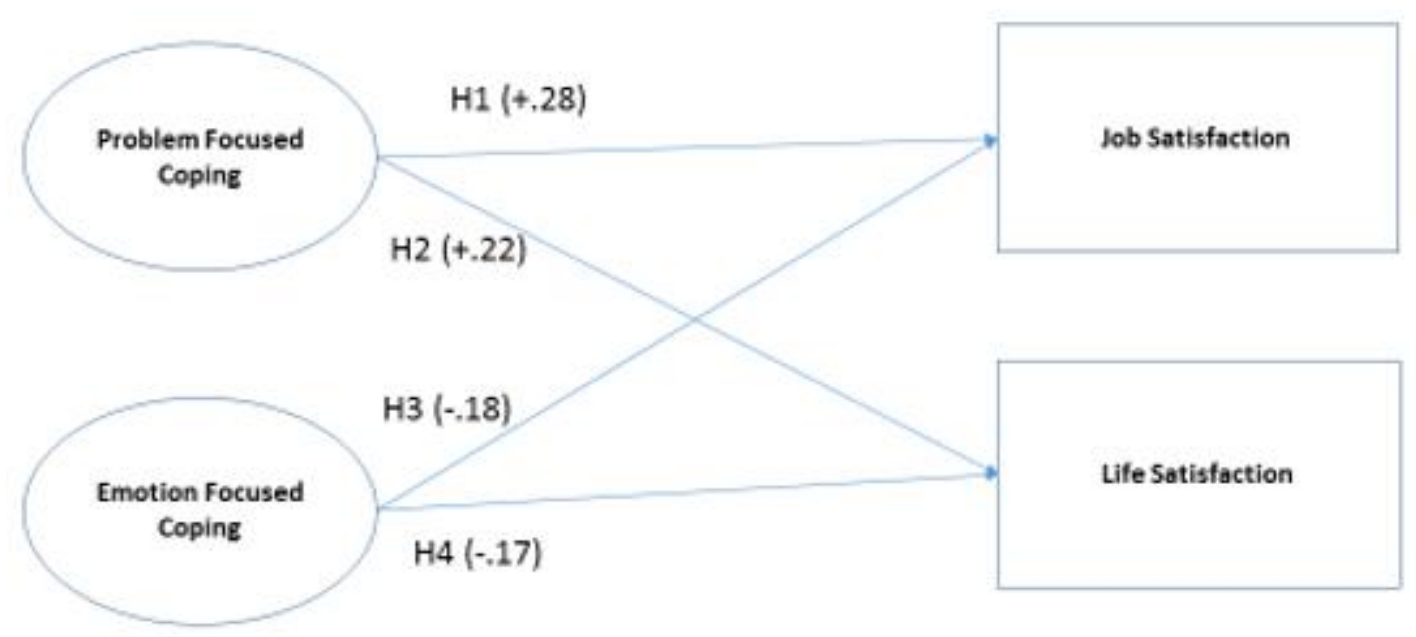

Figure 2. Model with Standardized Regression Coefficients

Source: Own elaboration

\section{Conclusion and Recommendation}

This paper shows the importance of coping in salesperson's daily work life. If the salespeople use problemfocused coping then they can increase job satisfaction and life satisfaction. If they use emotions focused coping then it will reduce job satisfaction and life satisfaction. This is very critical for companies as it affects their daily work. Happy people are more successful, exhibit more positive emotions most of the time, earn a higher income, show numerous adaptive job characteristics, and exhibit positive perceptions of themselves and others than their less happy counterparts. Right coping helps salespeople develop positive feelings, increase the frequency of positive emotions, improve the morale of working teams, enhance their self-esteem, and promote positive attitudes toward themselves and others, which may improve their job performance.

Managers should train their salespeople in the right way of coping. Salespeople should be trained in problemfocused coping. This will reduce stress, eliminate the source of stress, and work on getting rid of the problem itself. Salespeople who use emotion-focused coping should be informed the negative effect of coping and how it leads to a reduction in job satisfaction and reduction in life satisfaction. Educating the salespeople in the right way of coping will lead to an increase in satisfaction, reduction in intent to leave the job and reduction in 
ISSN (online) - 2520-6311; ISSN (print) - 2520-6761

the cost of replacing those salespeople. Reduction in stress by using the problem-focused coping also leads to healthy salespeople. This has a huge financial impact on the organization. Both physiological and psychological unhealthy employees cost organizations billions of dollars annually.

\section{Job Satisfaction and Ethics}

Several studies have proved that the level of job satisfaction and life satisfaction affects the sale person's ethical climate. If salespeople feel happy and proud of their work environment, they are unlikely to engage in unethical behavior. Employees working in an environment where there is the right ethical environment, experience greater overall satisfaction with their job. So, the more ethical salespeople are, the happier and successful they are. Organizations that develop ethical climate improve the morale of the employees and enhance their self-esteem. This leads to the positive environment of the organization, which leads to improvement in life satisfaction. Organizations that emphasize a code of ethics in their day-to-day work, provide ethical training to individual employees, have salespeople who have a higher level of job satisfaction and a higher level of life satisfaction. At the same time, salespeople prefer to work for employers who fulfill ethical obligations and treat everybody in the company ethically. When top management is perceived as strong ethically and create an environment of ethics, the employees working are satisfied. If the employees are trained to cope in the right manner, it will lead to happy and satisfied employees. This will lead to more ethical behavior by the employees. There is a direct relationship between ethical behavior by managers and employee job satisfaction.

\section{References}

1. Arndt, A.D. and Harkins, J. (2013). A framework for configuring sales support structure. Journal of Business \& Industrial Marketing, 28(5), 432-443.

2. Aldwin, C. M., \& Revenson L. (1987). A. Does coping help? A re-examination of the relation between coping and mental health. Journal of Personality and Social Psychology, 53, 337-348.

3. Brashear, T.G., Boles, J.S., Bellenger, D.N., Brooks, C.M. (2003). An empirical test of trust-building processes and outcomes in sales manager-salesperson relationships. Journal of Academy of Marketing Science, 31(2), 189-200.

4. Brown, S.P., and Peterson, R.A. (1993). Antecedents and consequences of salesperson job satisfaction: meta-analysis and assessment of causal effects. Journal of Marketing Research, 30, 63-77.

5. Chabra, B. (2016). Work role stressors and employee ourcomes: Investigating the moderating role of subjective person-organization and person job fit perceptions in Indian organizations. International Journal of Organizational Analysis, 24, 390-414.

6. Churchill, G.A., Ford, N.M., Walker, O.C. (1974). Measuring the job satisfaction of industrial Salesmen. Journal of Marketing Research, 11(3), 254-260.

7. Cooper, Cary L., Philip, J. Dewe, and Michael, P. O’Driscoll. (2001). Organizational Stress: A Review and Critique of Theory, Research, and Applications, Thousand Oaks, CA: Sage Publications.

8. Darmody, M. and Smyth, E. (2016). Primary school principals ' job satisfaction and occupational stress. The International Journal of Educational Management, 30, 115-128.

9. Diener, E., Emmons, R.A., Larsen, R.J., and Griffin, S. (1985). The satisfaction with life scale. Journal of Personality Assessment, 49, 71-75.

10.Folkman, Susan and Richard Lazarus (1980). An Analysis of Coping in a Middle-aged Community Sample. Journal of Health and Social Behavior, 21(September), 219-239.

11.Folkman, Susan and Richard Lazarus (1985). If It Changes It Must be a Process; A Study of Emotion and Coping During Three Stages of a College Examination. Journal of Personality and Social Psychology, 48(January), 150-170.

12.Ichniowski, C., Shaw, K. and Rennushi, G. (1997). The effects of human resource management practices on productivity: A study of steel finishing lines. American Economic Review, 87, 291-313.

13.Johnson, J.T., Griffeth, R.W. and Griffin, M. (2000). Factors discriminating functional and dysfunctional salesforce turnover. Journal of Business \& Industrial Marketing, 15(6), 399-415.

14.Koeske, G. F., \& Koeske R. D. (1993). A preliminary test of a stress-strain-outcome model for re conceptualizing the burnout phenomenon. Journal of Social Service Research, 17(3/4), 107-133.

15.Kraft, F. B., Maity, D. and Porter, S. (2019). The salesperson wellness lifestyle, coping with stress and the reduction of turnover. Journal of Business \& Industrial Marketing, 34(2), 347-359.

16.Lazarus, Richard and Susan, Folkman (1984). Stress, Appraisal, and Coping, New York: Behavioral Science Books.

17.Locke, E.A. (1969). What is job satisfaction? Organizational Behavior and Human Performance, 74, 309-336. 
18.Mayo, M. and Mallin, M. (2014). Antecedents and anticipated outcomes of superstitious behavior among professional salespeople. Journal of Business \& Industrial Marketing, 29(3), 227-237.

19.Mulki, J.P., Jaramillo, F., Locander, W.B. (2006). Effects of ethical climate and supervisory trust on salesperson's job attitudes and intentions to quit. Journal of Personal Selling and Sales Management, 26(1), 19-26.

20.Niessen, C., Muller, T., Hommelhoff, S. and Westman, M. (2018). The impact of preventive coping on business travelers' work and private life. Journal of Organizational Behavior, 39(1), 113-127.

21.Said, M. (2016). Workplace stress: Health epidemic of the 21st century. Malta Chamber, Available at: http://www.maltachamber.org.mt/en/workplace-stress-health-epidemic-of-the-21 st-century.

22. Smith, N. (2012). Employees reveal how stress affects their jobs. Business News Daily, March 28, 8:37am EST.

23.Srivastava, R. and Sager, J. (1999). Influence of personal characteristics on salespeople's coping styles. Journal of Personal Selling and Sales Management, 19, 47-58.

24.Srivastava, R. and Tang, T. L. P. (2015). Coping intelligence: Coping strategies and organizational commitment among boundary spanning employees. Journal of Business Ethics, 30, 525-542.

25.Srivastava, Rajesh V. and Tang, T.L.P. (2018). Coping intelligence theory: coping strategies, satisfaction and sales commission. The Journal of Business \& Industrial Marketing, 33, 610-624.

26.Stewart, W. F., Ricci, J. A., Chee, E., Hahn, S. R., \& Morganstein, D. (2003). Cost of lost productive work time among US workers with depression. Journal of the American Medical Association, 289, 3135-3144.

27.Strutton, D. and Lumpkin, J. (1993). The relationship between optimism and coping styles of salespeople. Journal of Personal Selling and Sales Management, 13, 71-82.

28.Strutton, D. and Lumpkin, J. (1994). Problem- and emotion-focused coping dimensions and sales presentation effectiveness. Journal of the Academy of Marketing Science, 22, 28-37.

29.Strutton, D., Pelton, L. E., \& Lumpkin, J. (1995). Personality characteristics and salespeople's choice of coping strategies. Journal of the Academy of Marketing Science, 23, 32-140.

30.Tang, T.L.P. and Hammontree, M.L. (1992). The effects of hardiness, police stress, and life stress on police officers' illness and absenteeism. Public Personnel Management, 21, 493-510.

31.Tang, T.L.P. (2007). Income and quality of life: Does the love of money make a difference? Journal of Business Ethics, 72(4), 375-393. 